Managing Waters of The Nile:

\title{
Controversy Between Egypt And Ethiopia And The Role Of International Community
}

\section{Monika Krishna}

School of International Studies, Jawaharlal Nehru University, New Delhi onika29_isl@jnu.ac.in

The Ethiopian state announced the construction of Africa's largest dam called "The Great Ethiopian Renaissance Dam" (GERD) over the Nile river in 2011. Egypt, which has historically enjoyed monopoly over the river water opposed the construction stating that its economy is dependent on Nile river for more than 90 percent of its fresh water needs, making it an issue of core national interest. Sudan, another downstream state has also been apprehensive about water diversion as a result of such massive dam. While the issue came to the negotiating table soon after its construction was announced in 2011, despite repeated calls from Egypt to stop the construction works till a final agreement is reached, Ethiopia continued the construction unfettered and today, after almost a decade, dam construction is nearly completed while the negotiations are still inconclusive. After multiple attempts of negotiations failed between the three states, they started calling for the international intervention. This article discusses the issue at length and argues for a neutral and constructive intervention by the international community rather than making the region a conflict ground of regional and international politics.

The primary stream of the Nile is known as the White Nile and it originates in the Great Lakes region of Africa. Other stream originates in Ethiopian lake Tana and is known as the Blue Nile. The White Nile and the Blue Nile meet at the capital of Sudan, Khartoum and finally flows through Egypt before opening up into the Mediterranean Sea. Though White Nile is longer, it is Blue Nile which contributes to more than 80 percent of the Nile water. Along with two other branches that drain Ethiopian highlands, almost 85 percent of Nile water originates in Ethiopia . With increasing population pressure and climate change looming large, the water of Nile is being increasingly contested among its riparian states. Such contestations are also fuelled by the colonial times agreements which grant dominant share of water to Egypt and Sudan, leaving other states with 
hardly any water share.

\section{Historical agreements over Water sharing and recent efforts}

One of the initial and most cited agreement in the recent crisis has been the Nile Waters Agreement of 1929 between Egypt and the Great Britain (which represented its colonies of Uganda, Kenya, Tanzania and Sudan). This agreement granted historical rights to Egypt over Nile water. It allocated 48 billion cubic metres of Nile water to Egypt and 4 billion cubic metres to Sudan, out of a total 84 billion cubic metres. Additionally, it granted veto power to Egypt over any construction projects undertaken in the upstream states if it reduces the amount of water flowing to Egypt. Ethiopia and other riparian states were not party to this agreement.

In 1959, Egypt and independent Sudan struck another agreement over water sharing which essentially reinforced the provisions of 1929 agreement but increased the allocation of water to Egypt and Sudan to 55 billion cubic metres and 18.5 billion cubic metres respectively. This accounts to only a shade less than 90 percent of total Nile water while it is believed that 10 percent of water is lost to evaporation and seepage. Other nine riparian states were left with negligible volume and have occasionally questioned the legitimacy of such agreements, asserting their rights to water. The disproportionate share of Egypt over Nile water on one hand leaves other states deprived of water and anguished, and on the other hand has made Egypt highly dependent in the allocated water share. In 1979, the Egyptian president, Anwar Sadat stated that "the only issue that could take Egypt to war again is water." Similar sentiments are shared by other leaders of Egypt in subsequent years with the recent one by the Egyptian foreign minister in 2019 that, "for Egypt, the matter of the Nile is a matter of life and death."

\section{After announcement of the GERD}

Egypt had raised issues over the dam immediately after it was announced in 2011. The apprehensions were fuelled as Ethiopian parliament ratified the controversial treaty to replace colonial era agreements that granted Egypt the biggest share of Nile water. Sudan also merged voices with Egypt's opposition and sought clear guidelines of management and operation, it was however a smaller party to the conflict. The tripartite talks started in 2011 and narrowed down to a conclusion in 2015 when a document called declaration of principles was signed between the three parties. It was made clear through this document that the downstream countries should not be negatively impacted by construction projects upstream. The principles of cooperation, development, dam security, dam's reservoir filling time, its operation policies and peaceful 
settlement of disputes etc. were taken into account in the document and all the three countries welcomed it. It was agreed that downstream countries would be given priority in purchasing electricity generated through the dam. However, as the events progressed, a sense a mistrust continued to linger and Egypt claimed that Ethiopia is not sticking to the said agreement. As apprehensions started to flare up and tripartite meetings became fruitless spaces, towards the end of 2017, Egypt called for international intervention of World Bank as technical mediator(Xuequan, 2017).

Ethiopia's position has been that the dam would be a boon for its economy without holding back Egypt from any endeavours. From being one of the poorest countries in 1990s, Ethiopia has become one of the fastest growing economies in 2020 growing at about 10 percent per year. However, the country is still struck with poverty with more than half of the population lacking power supply. With the construction of GERD, Ethiopia's underserved population will be able to come out of the vestiges of the past underdevelopment. Additionally, it will help in containing the long-drawn problem of sedimentation to the farmers, will create thousands of jobs, provide clean water to millions helping control the spread of COVID-19 and also help in managing the effects of drought and flood. Moreover, with increasing concerns around fossil fuels causing warming up of the earth, the renaissance dam aims at providing clean and sustainable energy for consumption. It is expected to produce 6450MW of electricity after completion, enough for Ethiopia's domestic consumption and to earn foreign exchange through its exports. Thus, for Ethiopia, GERD is a one stop solution to multiple problem that country is facing today.

The contention multiplied when Ethiopia insisted on building the dam while the technical studies on its feasibility and operation by a third-party international company were going on. Egypt argued that the recommendations of the studies will be difficult to implement once the dam is completed and operating. Another major sticking point was filling time of the dam. Renaissance Dam has humungous capacity of 74 billion cubic metres. This is close to the amount of water allocated to the Egypt in a year. Ethiopia initially planned to fill up the reservoir in three years, which would mean a drastic reduction of water to Egypt during these years. However, after a strong opposition from Egypt, there has been a verbal agreement to fill the dam in seven to eight years, still less than 11 years that was asked by Egypt. Moreover, Egypt request to increase the number of lower water gates to ensure daily flow in case of malfunctioning was outrightly rejected by Ethiopian technical experts . For its part, Egypt delegation also rejected Ethiopia's request to store at least 3 billion cubic metres in the dam to carry out construction safety tests in 2016. 


\section{International Intervention}

After all the three countries agreed intervention in 2019, United States brokered the talks between the three parties in presence of the president of the World Bank from November 2019 to February 2020. Concrete outcomes and agreements were reached during series of talks among the three parties regarding rules of operation of the dam and mechanism of filling the reservoir in different conditions of drought and excessive drought. However, Ethiopia refused to sign the final deal alleging U.S. of being partisan of Egypt as president Trump supported Egypt's historical rights over the Nile water and commented that 'Egypt will simply destroy the dam if it became a threat'. Egypt called for an intervention by United Nations Security Council into the matter, which finally asked the African Union (AU) to facilitate the tripartite talks. AU-brokered talks were initiated in July 2020. It was observed by representatives of U.S., EU, AU commission, and technical/legal experts. After several rounds of talks, the contention could not be solved and stalemate continued over core issues like dispute resolution mechanism, operation of the dam and the filling time.

As the dispute over Nile water sharing is deepening, more countries are actively engaging themselves into it. Countries are increasingly aligning themselves to one party of the conflict. Subsequently, Egypt and Ethiopia are courting more countries to back them up fuelling the issue further. While it has become already complex, last year U.S. and recently European Union suspended financial aids to Ethiopia. China is already funding significant portions of the dam and may involve itself more in the region against the U.S. as dispute between the two powers is intensifying. Chinese stakes are high as it has provided USD16 billion loan to Ethiopia for development projects for which the electricity will be imperative. The issue needs to be managed rationally before the region becomes a microcosm of the larger power politics of the world.

Technical issues of the dam are overshadowed by the political discourses. The underlying technical issues on which dam's structure and its size might be questionable are being clouded by political complexities shaping up in the region. According to MIT's Abdul Lateef Jameel Laboratory in 2015, there were at least five important technical issues coming in the way of the building of the dam that required resolution. One of the most important of them being that if Aswan Dam (built by Egypt) and GERD are to be run simultaneously on Nile, their operation needs to be closely coordinated. To quote MIT research 'Nowhere in the world are two such large dams on the same river operated without close coordination'. Other issues pertain to the possibility of stored water being spilled into northwest end of reservoir, location and capacity of low-level release outlets, construction of electricity transmission lines to regional markets, siltation etc. 


\section{What can be the way forward?}

Though the talks over the issue have been going on since 2011 however, the focus is still on the problem and not on the solution. Egypt's water needs, Sudan's flood security and Ethiopia's economic development are the three ends of the triangulated issue. There needs to be an effective balance between the interests of the three states. Though Egypt is heavily dependent on Nile water for almost all of its needs due to its historical allocation, however, Nile water does not belong to any one country. An effective water sharing agreement needs to be reached with all the eleven countries of Nile as parties. Ample areas of cooperation are possible between riparian states of Nile. Egypt is industrially advanced, Sudan and South Sudan have huge agricultural lands in an otherwise largely desert continent, Lake Victoria provides huge fish wealth and recent project by Ethiopia will lead production of large amount of electricity. An effective and mutually beneficial engagement can be forged between these countries on various areas. Such agreement was attempted in 2010 with Nile Basin Initiative, however Egypt backed out fearing to lose its historical share of water. It is in everyone's and Egypt's own benefit to realise that water needs to be shared between all riparian states which will inevitably reduce Egypt's allocation but lead to a more stable region. Other countries will also have to give time to Egypt to adjust its needs and reform its agriculture sector which reportedly consumes most of the water and much of it quite wastefully.

With so many countries and their interests at stake, it must be constructed with utmost care and sense of responsibility. Technical flaws pin pointed by expert researches needs to be considered and resolved. Ethiopian economy has been growing at a high rate and a lot of it is fuelled by the foreign money that flows in. Since most of the dam construction is completed, nobody including Egypt is now asking to overturn the construction activity, however, the demands of technical precision and correction of flaws are rightfully made. Egyptian apprehensions cannot be underplayed as there are plenty examples of drying up of the river owing to construction of large and multiple dams, as the Hoover Dam and several others over Colorado River has led to drying up of the river and its delta in North Mexico. On the other hand, Ethiopia rightfully demands use of water for electricity production and further developments when its contribution to the Nile is as high as 85 percent of the water. It's important to strike a balance between needs of the two countries.

Third party technical experts must be deployed to review the technicalities and feasibility of the dam so that they can point out flaws and correct them accordingly. And if Ethiopia claims that 
Egypt's water share will not be impacted considerably, there needs to be a written agreement on penal and corrective measures if water supply reduces below certain threshold. In fact, United States recently initiated Mekong river dam monitor project to check operation and water levels of the dams constructed by China on the Mekong river, partly allaying the fears of downstream countries. Similar initiatives can be launched for the dams on the Nile river so that Ethiopia acts responsibly. Ethiopia and Egypt are highly integrated with the world economically and diplomatically, such integration must be utilised by the international community for stability and peace in the region. The conflict needs to change its course from being politically driven to being more rationally driven and the onus of this rationality lies on the international community.

\section{References}

Aman, A. (2016, January 11). Potential solutions to Egypt-Ethiopia dam dispute remain murky. Khartoum, Sudan, Sudan. Retrieved December 30, 2020, from https://www.almonitor.com/pulse/originals/2016/01/egypt-ethiopia-renaissance-dam-disputenegotiations.html

Gebre, S., \& Wainer, D. (2020, May 22). Why a Giant Hydropower Dam in Africa Worries the U.S. and China. Retrieved from Bloomberg Green: https://www.bloomberg.com/news/articles/2020-0521/diplomatic-pressure-mounts-on-ethiopia-over-filling-of-giant-dam

Kimenyi, M. S., \& Mukum Mbaku, J. (2015). The limits of the new "Nile Agreement". Khartoum: The brookings Institution.

Leithead, A. (2018, February 24). The 'water war' brewing over the new River Nile dam. Cairo, Egypt, Africa. Retrieved from https://www.bbc.com/news/world-africa-43170408

Moges-Gerbi, M. (2020, August 13). Tensions over Nile River dam project as heavy rain sows confusion. Adis Ababa, Ethiopia, Africa.

Mukum Mbaku, J. (2020). The controversy over the Grand Ethiopian Renaissance Dam. Adis Ababa: The Brookings Institution.

NILE-Sec. (2020, December 30). Nile basin Initiative cooperative framework agreement. Retrieved from Nilebasin.org: https://nilebasin.org/index.php/81-nbi/73-cooperativeframework-agreement

Nunzio, J. D. (2013). Conflict on the Nile: The future of transboundary water. Future Directions Intenational.

Sweet, R. (2016, Jan 21). French firm picked to study Ethiopia's mega dam as uneasy truce holds. Khartoum, Khartoum, Sudan. Retrieved 1230,2020 , from https://www.globalconstructionreview.com/markets/french-firm-picked-stu7dy-ethiop7ias- 


\section{me7ga-da7m/}

Xuequan, M. (2017, December 12). Egypt seeks World Bank as technical mediator in Ethiopia's dam issue. Beijing, Beijing, China. Retrieved 1230,2020 , from http://www.xinhuanet.com/english/2017-12/27/c_136853702.htm 